\title{
An Alternative to the Cosmic and Mechanic Metaphors for the Human Body? The House Illustration in Ma'aseh Tuviyah (1708)
}

\author{
ETIENNE LEPICARD*
}

In Ma'aseh Tuviyah, a Hebrew medical treatise published in Venice at the dawn of the eighteenth century, there is a magnificent illustration in which the human body is portrayed as a house. ${ }^{1}$ What was the function of such an illustration? What is its significance? In the following article I will postulate that such an illustration would have served primarily as a mnemonic device for (Jewish) students of medicine. It may also be seen, however, as a possible alternative to the mechanistic vision that has dominated our conception of the human body since the onset of the scientific revolution; an alternative with deep roots in Hebrew culture as well that in "the arts of memory".

In medieval medical treatises, the body is often portrayed in relation to the universe as a reflection of the heavenly bodies. Man is defined as a "little world" or microcosm, and the universe that he reflects as a "great world" or macrocosm ${ }^{2}$ - as, for example, in such pictures that note suitable points for blood-letting in reference to the signs of the zodiac. ${ }^{3}$ Some historians see this as proof that a familiarity with astrology would have been a prerequisite for the practice of learned medicine at the time. ${ }^{4}$ Without denying this, one might ask whether such books were not by the same token merely employing a simple

(C) Etienne Lepicard 2008

* Etienne Lepicard, MD, PhD, Sackler School of Medicine, Tel-Aviv University. At present: Research Fellow, Institute for the History of Medicine, JustusLiebig-University of Giessen, Germany; and Guest Lecturer, Program in Biological Thought, Open University, Israel; e-mail: etiennel@netvision.net.il

A previous version of this paper was presented at ASA Decennial Conference: 'Anthropology and Science', Manchester, UK, 14-18 July 2003; and in poster form at the 38th International Congress on the History of Medicine, Istanbul, Turkey, 1-6 September 2002 and at the 4th Research Fair of Sackler Faculty of Medicine, 14 April 2003. This paper has greatly benefited from the comments of many participants to these sessions and especially those of my colleague at Tel Aviv University, Yehiel Barilan, on the works of Frances Yates and Mary Carruthers on the arts of memory. Special thanks are due to Shmuel Sermoneta-Gertel for his English translation, and to Reuven Bonfil, from the Hebrew University, and to the anonymous reviewers for their helpful comments.

\footnotetext{
${ }^{1}$ Tobias Cohen, Ma'aseh Tuviyah, Venice, 1708, folio 106 .

${ }^{2}$ For an overview on the analogy between microand macrocosm, see George Boas, 'Macrocosm and Microcosm', in Philip P Wiener (ed.), Dictionary of the history of ideas, 5 vols, New York, Charles Scribner's Sons, 1973-74, vol. 3, pp. 126-31. On the history of the idea in Jewish thought, see Zvi Almog, 'Critical edition of Moses Ibn Tibbon's 'Olam Katan with an essay on the history of microcosm in medieval Jewish philosophy' (PhD Dissertation), Philadelphia, Dropsie College for Hebrew and Cognate Learning, 1966, and more recently: Jacob Haberman, 'Introduction', in Saul Horowitz, The microcosm of Joseph ibn Saddiq, Madison, NJ, Fairleigh Dickinson University Press; London, Associated University Presses, c.2003.

3 'The stars and the human body,' in Apocalypse, ca. 1420, fol. 41r, MS 49, Wellcome Library, London, reproduced in Nancy G Siraisi, Medieval and early Renaissance medicine: an introduction to knowledge and practice, University of Chicago Press, 1990, p. 112. This picture is also accessible online under "zodiac man" at http://medphoto.wellcome.ac.uk/

${ }^{4}$ Siraisi, ibid., pp. 67-8.
} 


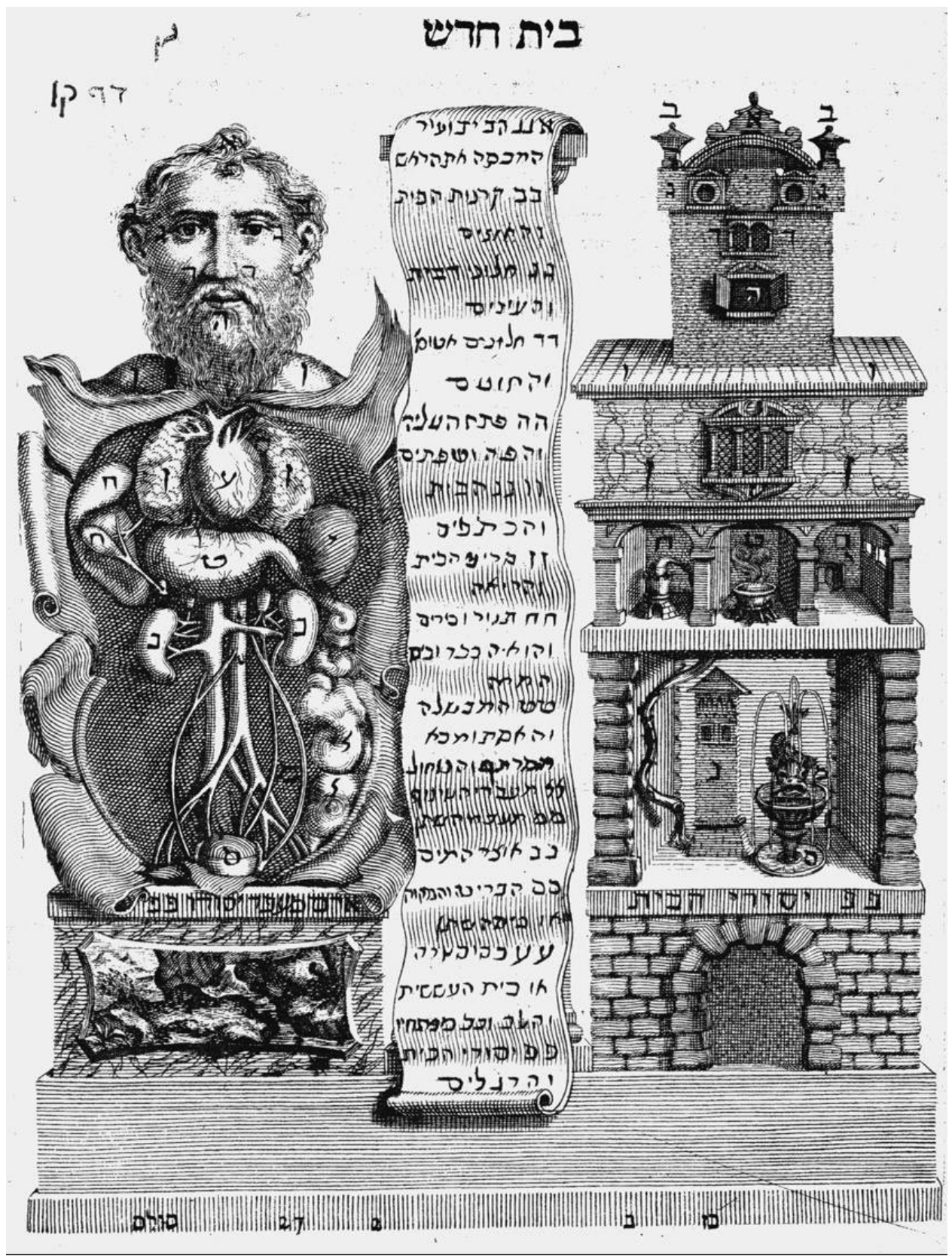

Figure 1: The human body as a house, from Tobias Cohen, Ma'aseh Tuviyah (1708), folio 106a. (Berman National Medical Library, Hebrew University of Jerusalem.) 


\section{The House Illustration in Ma'aseh Tuviyah (1708)}

mnemonic device in a period in which culture was still largely oral, thereby making it easier for students (and physicians) to remember the different phlebotomy points and their indications. ${ }^{5}$ Some have also suggested that the perception of the human body as subject to celestial influences reflects a sense of dependence upon the transcendent- the predominant view in the Middle Ages, in keeping with the Christian doctrine developed by the Catholic Church at the time. ${ }^{6}$ Whatever the reason, the microcosm metaphor undoubtedly occupied a central place in medieval medical representations of the human body. ${ }^{7}$

Conversely, the portrayal of the human body as a machine can be seen as the most significant mark of the changes that medicine underwent at the beginning of the modern era. The observation, quantification and calculation of forces have become an integral part of the study of the human body. ${ }^{8}$ This mechanistic representation can thus be seen as emblematic of the power that technology and science have afforded over the body in the modern era, ${ }^{9}$ even if the ancient conceptions persisted together with the new ones for a long time. ${ }^{10}$

Between the ancient cosmic conception and this new mechanical conception of the body, stand the renewal of dissections and the evolution of anatomical representations, both participating in the new visual culture of the Renaissance. ${ }^{11}$ We can thus ask whether Descartes' (1596-1650) metaphor of the man-machine, later taken up by La Mettrie (1709-1751), offered the only possible alternative to the microcosm, or whether he simply adopted a concept that would later come to dominate all others. ${ }^{12}$ Even if the illustration in Ma'aseh Tuviyah cannot in itself provide a satisfactory answer to this question, it does supply evidence that such alternatives indeed existed, and highlights the importance of the social and cultural elements that underlie these representations.

\footnotetext{
${ }^{5}$ Frances A Yates, The art of memory, University of Chicago Press, 1974 (1966), especially pp. 51-4 for the use of the Zodiac by Metrodorus of Skepsis. More recently, see the works of Mary Carruthers, The book of memory and The craft of thought, both published by Cambridge University Press, 1990 and 1998 respectively. For an exploration of the art of memory "hidden in the rhetoric of more recent forms of intellectual discourse", see Patrick H Hutton, 'The art of memory reconceived: from rhetoric to psychoanalysis', J. Hist. Ideas, 1987, 48: 371-92. In this article, Hutton suggests that the art of memory was not only a way to remember but also a way of representing and so of knowing the world.

${ }^{6}$ A Synnott, The body social: symbolism, self and society, London, Routledge, 1993, pp. 22-7.

${ }^{7}$ In the West, of course. For a comparison with China on blood-letting, see, for instance, Shigehisa Kuriyama, The expressiveness of the body and the divergence of Greek and Chinese medicine, New York, Zone Books, 1999; pp. 201-7.

${ }^{8}$ Mirko D Grmek and Raffaele Barnabeo, 'La machine du corps', in M D Grmek and B Fantini (eds), Histoire de la pensée médicale en Occident, vol. 2, De la Renaissance aux Lumières, Paris, Seuil, 1997, pp. 7-36; Yves Gingras, Peter Keating, Camille Limoges, Du scribe au savant. Les porteurs du savoir
}

de l'antiquité à la révolution industrielle, Paris, PUF, 2000, especially ch. 9, pp. 289-329.

${ }^{9}$ See Synnott, op. cit., note 6 above. See also Alfred W Crosby, The measure of reality: quantification and western society, 1250-1600, Cambridge University Press, 1997.

${ }^{10}$ Andrew Wear cites here the example of Harvey versus Descartes. See, Andrew Wear, 'Medicine in early modern Europe, 1500-1700', in L I Conrad, M Neve, V Nutton, R Porter, A Wear, The western medical tradition $800 \mathrm{BC}$ to $\mathrm{AD} 1800$, Cambridge University Press, 1995, pp. 215-361, on pp. 335-6.

${ }^{11}$ See Andrea Carlino, 'Representing the body: the visual culture of Renaissance anatomy', in his Paper bodies: a catalogue of anatomical fugitive sheets 1538-1687, Medical History, Supplement no. 19, London, Wellcome Institute for the History of Medicine, 1999, pp. 5-45.

${ }^{12}$ The term "metaphor" is used here for both the cosmic and mechanistic conceptions of the body rather than in the usual relatively narrow rhetorical sense. I thus point to its broader anthropological signification as one of the "mechanisms of the mind", i.e. "Our ordinary conceptual system, in terms of which we both think and act, is fundamentally metaphorical in nature." See George Lakoff and Mark Johnson, 


\section{Etienne Lepicard}

In this article, I will introduce the metaphor of the house employed by Tobias Cohen to represent the human body at the beginning of the eighteenth century, and attempt to determine its significance, drawing upon the book itself, and considering the spirit of the medical doctrine to which the author subscribed: that of iatrochemistry. This approach perceived the functions of the body in terms of a distillery, a fact which helps explain certain elements of the illustration. I will suggest that a metaphor of this kind also stems from the author's own communal experience. Thus, the fact that he does not employ just any house, but one that forms a part of the defensive walls of a fortified city, in my opinion evokes Tobias's Jewish communal experience at Padua in a less hostile environment by contrast to what he had experienced at Frankfurt-on-Oder. ${ }^{13}$ In order to demonstrate this, I will rely on elements of Tobias's personal history, appearing at the beginning of the book, on the author's remarks in the chapter devoted to pathology, in which the illustration appears, and on the Jewish sources used by Tobias in his text. The article is thus divided into three parts: a brief account of the author's life, followed by bibliographical information on the book in which the illustration appears, and finally, a discussion of the illustration itself, its function and its metaphorical significance.

\section{Biography of Tobias Cohen (1652-1729)}

Almost everything we know about Tobias Cohen is gleaned from his own book. ${ }^{14}$ One of the most recent accounts of Tobias and Ma' aseh Tuviyah is that of David Ruderman in his book: Jewish thought and scientific discovery in early modern Europe. ${ }^{15}$

Tobias was born in Metz in 1652, into a learned Jewish family. His grandfather, Eleazar Cohen, emigrated from Safed (then in the Ottoman province of Damascus), to settle in Cracow (Poland), where he studied medicine. His father, Moses, was both a physician and a rabbi. He migrated to France at the onset of the persecutions instigated by the Cossack leader Bogdan Chmielnicki in $1648 .{ }^{16}$ Following the death of his father, when he was nine years old, Tobias was sent back to Cracow, where he received a traditional Jewish education.

At the age of twenty-five, accompanied by his friend Gabriel Felix of Brody, Tobias went to study medicine at Frankfurt-on-Oder. Soon, however, the discrimination the two friends suffered drove them to abandon Frankfurt for a more open university: that of Padua, near Venice. ${ }^{17}$ In Padua they attended the preparatory school for Jewish medical students

Metaphors we live by, University of Chicago Press, 1980, p. 3.

13 When speaking about "hostile environment", I am referring to what Tobias tells us in his book about his own experience, and the explanation he gives for his moving from Frankfurt-on-Oder to Padua together with his friend, Gabriel Felix of Brody. I have no intention, however, of entering into the actual historiographical debate about this issue.

${ }^{14}$ Tobias Cohen, Ma'aseh Tuviyah (in Hebrew), first edition, Venice, 1708.

${ }^{15}$ David B Ruderman, Jewish thought and scientific discovery in early modern Europe, Detroit,
Wayne State University Press, 2001(c. 1995), pp. 100-17, 229-55. For biographic information, see also J O Leibowitz, 'Tobie Cohen, auteur médical de langue hébraïque (1652-1729)', Revue d'Histoire de la Médecine Hébraïque, 1964, 63: 15-24.

${ }^{16}$ See S A Goldberg and A Derczansky, 'Les juifs du moyen âge à nos jours: monde Achkenaze', in S A Goldberg (ed.), Dictionnaire encyclopédique du judaïsme, Paris, Du Cerf, 1993, pp. 1288-332, on pp. 1297-8.

${ }^{17}$ For general background on the University of Padua, see J J Bylebyl 'The school of Padua: humanistic medicine in the sixteenth century', in 


\section{The House Illustration in Ma'aseh Tuviyah (1708)}

founded by Solomon Conegliano (1642-1719)—himself a graduate of the city's medical university. ${ }^{18}$ Tobias and Gabriel obtained their doctorates in medicine and philosophy at Padua in $1683,{ }^{19}$ and Tobias went on to become a physician at the Sultan's court, residing at Adrianople and Constantinople (present-day Edirne and Istanbul respectively), before retiring to Jerusalem in 1715 , where he lived until his death in $1729 .^{20}$

This family saga, from Safed to Poland, France, Italy, the Ottoman empire, and finally Jerusalem, resembles the experiences of many European Jewish savants of the early modern period. ${ }^{21}$ European conflicts-such as the intellectual and cultural challenges that marked the development of new sciences in a period of uncertainty and constant change-resonate in Tobias's work.

\section{Bibliography of Ma'aseh Tuviyah, 1708}

Tobias's book is an encyclopaedic work in two main parts-one devoted to theology and scientific knowledge in general, and the other to medicine. ${ }^{22}$ According to the text on the frontispiece, which bears a portrait of Tobias, the manuscript would appear to have been completed in 1700. The publication licence from the University of Padua however-issued by the Franciscans and appearing at the end of the book-is dated 7 June 1708. One of the letters in the book's introduction would seem to suggest that the discrepancy between the two dates is related to the role played by Solomon Conegliano, who was, at Tobias's behest, responsible for its publication in Venice. ${ }^{23}$

C Webster (ed), Health, medicine and mortality in the sixteenth century, Cambridge University Press, 1979, pp. 335-70; and Brendan Dooley, 'Science teaching as a career at Padua in the early eighteenth century: the case of Giovanni Poleni', History of Universities, 1984, 4: 115-41. For the Jewish context, see David B Ruderman, 'The impact of science on Jewish culture and society in Venice (with special reference to Jewish graduates of Padua's medical school)', in David B Ruderman (ed.), Essential papers on Jewish culture in Renaissance and Baroque Italy, New York University Press, 1992, pp. 519-53.

${ }^{18}$ Ruderman, op. cit., note 15 above, pp. 111-12. See also the document published by Dubnov asserting that Tobias registered as a Polish Jew living in the ghetto: "(1681.30.XII.). Il Sigr. Tobia Moschide ... hebreo Polacco, sum [sic] primo anno di studio in Padova, habita in Ghetto, matricolato d'ordine dell' Eccel. Sigr. Capitaneo.” Simon Dubnov, 'Jewish students at the University of Padova (in the seventeenth and eighteenth century)', Sefer hashana lihude America (in Hebrew), 1931, 1: 216-19, on p. 219.

${ }^{19}$ D Kaufmann, 'Trois docteurs de Padoue: Tobias Moschides, Gabriel Selig B. Mosé, Isak Wallich', Revue des Etudes Juives, 1889, 18: 293-8; Daniel Carpi, 'Jewish graduates of the University of Padua during the sixteenth century' (in Hebrew), in idem, Between Renaissance and ghetto: essays on the history of the Jews in Italy in the fourteenth and seventeenth centuries (in Hebrew), Tel

Aviv, University Publishing Project, 1989, pp. 96-130.

${ }^{20}$ For background, see, for example, J Hacker, 'The intellectual activity of the Jews of the Ottoman empire during the sixteenth and seventeenth centuries', in I Twersky and B Septimus (eds), Jewish thought in the seventeenth century, Cambridge MA, Harvard University Press, 1987, pp. 95-135. I would like to point out the excellent, as yet unpublished work of a younger colleague of mine at the University of Tel-Aviv: Y Ecker, 'Jewish physicians in the Ottoman empire as agents of cultural transfer, 1650-1750' (in Hebrew), and to thank him for having allowed me to read it.

${ }^{21}$ For example, we could cite Yerushalmi's classic study on another such Jewish physician, Isaac Cardoso: Y H Yerushalmi, From Spanish court to Italian ghetto: Isaac Cardoso: a study in seventeenthcentury Marranism and Jewish apologetics, New York, Columbia University Press, 1971.

${ }^{22}$ In effect, following the part devoted to medicine proper, there are further chapters, presented as independent sections. These sections, however, are not as extensive as the first two parts, and in any event are all related to medicine.

${ }^{23}$ Solomon Conegliano, 'Preface to Ma'aseh Tuviyah' (in Hebrew), in Tobias Cohen, Ma' aseh Tuviyah, Venice, 1708. It is not unusual to find 1707 as 


\section{Etienne Lepicard}

According to Ruderman, the work was printed five times at Venice between 1708 and 1850, followed by seven further editions published elsewhere-most recently in Brooklyn, New York, in 1974, and in Jerusalem, in 1967 and 1978. Ruderman thus characterizes Ma' aseh Tuviyah as "the most influential early modern Hebrew textbook of the sciences, especially medicine". 24

One of the book's main characteristics is its attempt to associate the "new sciences" with the traditional Jewish view of science in general and medicine in particular. As we have noted, the book is organized in encyclopaedic fashion. The first part comprises five chapters: 'The Upper World' (corresponding more or less to metaphysics), 'The World of the Spheres' (astronomy), 'The Lower World' (geography), 'The Little World' or 'Microcosm' (ethnography), and 'The Foundations of the World' (alchemy). The second part comprises three main chapters: 'A New Land', 'A New House' and 'The House Watch' or 'Guard'. This corresponds to the traditional division of medical texts into three parts: physiology, pathology and therapy (limited here to hygiene). A third part includes: 'A Garden Enclosed' (gynaecology and obstetrics), 'Fruit of the Womb' (paediatrics), and 'A Fountain Sealed' (on sterility). It should be noted that while the chapter titles in the first part of the book relate to the idea of the "world", and those of the second part to the theme of novelty and the house, the headings in the third part all derive from the Bible, particularly the Song of Songs. ${ }^{25}$ The book also includes a section on medical botany and a list of remedies. $^{26}$

\section{Iconography of Human Anatomy: The House Metaphor}

Another important feature of the book is the scientific and medical illustrations it provides. As the British medical historian Nigel Allan remarked, Ma'aseh Tuviyah is "one of the first books printed in Hebrew to do so". ${ }^{27}$ These are especially beautiful in the editio princeps. Clearly done by a professional artist, a careful examination of the book and its main illustrations did not, however, provide any indication of who this person could have been. Further research is obviously needed here. ${ }^{28}$

the date of publication. The date of the publication licence can help resolve a debate I believe to be due to the fact that the Hebrew date (tav-samekh-zayin 5467) can correspond both to 1707 and to 1708 . For the date 1707 , see, for example, Leibowitz, op. cit., note 15 above, p. 15; and Ruderman, op. cit., note 15 above, p. 229. For 1708, see D A Friedman, 'Tuviyah Katz, the physician', in Kovetz Refui (in Hebrew), 1940: 33-43; and N Allan, 'A Jewish physician in the seventeenth century', Med. Hist., 1984, 28: 324-8, especially p. 326.

${ }^{24}$ Ruderman, op. cit., note 15 above, p. 229.

${ }^{25}$ Song of Songs 4:12 for "a garden enclosed" and "a fountain sealed"; and Genesis 30:2 or Isaiah $13: 18$ for "fruit of the womb".

${ }^{26}$ See note 22 above.

${ }^{27}$ Allan, op. cit., note 23 above, p. 326.

\footnotetext{
${ }^{28}$ A possibility would be to identify the press in which the book was printed in order to discover who its illustrators were and if there was collaboration between them and the author, or perhaps with Conegliano, who was in charge of bringing the book to the press (see note 23 above). I wish to thank here one of the anonymous reviewers for this suggestion of further research. Also the architectural style of the house has not been researched in spite of the historical data which might well be drawn from it. I focus rather on the metaphorical significance of the illustration and its possible alternative status to better known metaphors of the body as the microcosm and the machine.
} 


\section{The House Illustration in Ma'aseh Tuviyah (1708)}

The illustration presented here follows the introduction to the chapter on pathology in the medical part of the book, the section entitled 'A New House'. The introduction and its accompanying illustration serve as a prologue to the material presented in the chapter itself, following a a capite ad calcem (head to foot) order-in use at least since the times of Avicenna, ${ }^{29}$ and especially conducive to the invention of mnemonic devices. $^{30}$

To the left of the illustration, is the figure of a man with open chest and abdomen, so that the principal internal organs are visible. A Hebrew scroll separates this figure from that of a house comprising four floors, ${ }^{31}$ to the right of the illustration. In accordance with common practice in anatomy texts of the period, the organs are marked with letters, for reference purposes. ${ }^{32}$ On the scroll, the letters, in alphabetical order, are followed by the name of the designated part of the house, and that of the corresponding organ. The face of the man is intact, giving the figure as a whole an animated expression. It is worth noting that only the principal internal organs are represented.

Following a brief introduction, the text on the page preceding the illustration further develops the metaphor presented on the scroll. At first glance, one might think that Tobias had failed to incorporate Harvey's revolutionary explanation of the role of the heart in the circulatory system, because at the centre of the illustration stands a steaming cauldron, calling to mind the ancient representation of the heart as the place in which the blood is warmed. Upon careful examination however, the reference letters and accompanying text clearly reveal that the cauldron is located in the kitchen of the house, corresponding to the stomach, whereas the heart is situated on the floor above, hidden behind a latticework grille. This place is worthy of the "master of the house", as Tobias terms the heart, where it can benefit from fresh air without being too exposed. ${ }^{33}$ The "kitchen" level below corresponds to the bodily functions as understood at the time by the adherents of iatrochemistry, a school of thought Tobias appears to have held in great esteem, which focused primarily on processes such as effervescence and fermentation as the basis of physiology. ${ }^{34}$

\footnotetext{
${ }^{29}$ See Siraisi, op. cit., note 3 above, pp. $84-5$.

${ }^{30}$ On the order of presenting the material in earlymodern anatomical treatises, see Rafael Mandressi, Le regard de l'anatomiste: dissections et invention du corps en occident, Paris, Seuil, 2003, especially pp. 118-132. Mandressi shows the progressive evolution from a presentation following the order of dissection to one following the order of composition (by which term he means, a theoretically reconstituted order).

${ }^{31}$ According to Mandressi, the traditional presentation was a three "bellies" one-venter inferior (abdomen), venter medius (thorax), venter superior (head). Mandressi, ibid., pp. 117-21. Here only the abdomen and thorax are open but are divided, nevertheless, into three storeys.

${ }^{32} \mathrm{~S}$ Kusukawa, 'Illustrating nature', in M Frasca-Spada, and N Jardine (eds), Books and
}

the sciences in history, Cambridge University Press, 2000, pp. 90-113.

${ }^{33}$ On the incorporation of Harvey's revolution in the work of Tobias, see J O Leibowitz 'Harveian items in Hebrew medicine', Harofé HaIvri (English part of the current edition), 1957, 30(2): 134-8 (English part of Annual combined Israel edition, 1957, 30: 229-33).

${ }^{34} \mathrm{M}$ Lindemann, Medicine and society in early modern Europe, Cambridge University Press, 1999 , p. 79. Ruderman, op. cit., note 15 above, pp. 244-9. See also A G Debus, 'La médecine chimique', in Grmek and Fantini (eds), op. cit., note 8 above, vol. 2, pp. 37-59, and, of course, his classic study:

A G Debus, The chemical philosophy : Paracelsian science and medicine in the sixteenth and seventeenth centuries, New York, Science History Publications, 1977. 


\section{Etienne Lepicard}

Regarding the origin of the metaphor of the house itself, some historians have suggested that it can be found in Harvey's Prelectiones anatomie universalis: lectures delivered in 1616 at the College of Physicians in London. ${ }^{35} \mathrm{I}$ do not believe any direct influence can be proven, but that recourse to a common metaphor should be attributed to a common source, such as a mnemonic device in use at the time, which Tobias enriched with his own cultural background. Apart from Harvey, the house metaphor had already been employed before Tobias by the great poet John Donne. Although mutual inspiration between John Donne and William Harvey seems very likely, ${ }^{36}$ since they were contemporaries, such a source of inspiration would appear to be too far removed from Tobias to sustain this point of view. Certainly, Tobias cites Harvey and his heart theory, but the metaphor is far from central to Harvey's work, as it is in that of Tobias. For Harvey, in effect, the metaphor appears in a fragmented fashion over a number of lectures: the thorax as the "parlour" appears on folio 4, the stomach as "kitchen" or "shop" on folio 6, while he speaks of "furnaces to draw away phlegm, rayse the spirit" on folio $24 .{ }^{37}$ Finally, one can ask whether Harvey's lectures could have reached Tobias at all, as they were not published in book form, to the best of my knowledge, until the late nineteenth century; a fact which, if confirmed, would further prove the tenuousness of the theory that Harvey exerted a direct influence on Tobias, and would require another explanation for the appearance of this metaphor in the works of both authors. ${ }^{38}$

It is important to note here that both Harvey and Tobias studied at Padua. Harvey spent two years there at the beginning of the seventeenth century and, as we have seen, Tobias graduated from the university in $1683 .{ }^{39}$ At Padua, the medical curriculum combined the new discoveries in the field of anatomy with study of the classics, such as Galen's Ars medica and Avicenna's Canon, ${ }^{40}$ which explains the fact that Tobias's writings reflect both classical and contemporary influences. Whatever the case, it appears correct to say that this metaphor is well suited to the development of the study of human anatomy and its representation in the baroque period, alongside more traditional representations deriving from the classical approach to remembering knowledge. As Frances Yates first showed in The art of memory, people have used architectural devices as aids to memory ever since antiquity. ${ }^{41}$ The pedagogical purpose of Tobias's work should be stressed here. Without addressing the entire issue of the reasons behind Tobias's decision to write his book in Hebrew, it seems quite clear that he wanted to bring the benefits of the

\footnotetext{
${ }^{35}$ Leibowitz, op. cit., note 15 above; and Allan, op. cit., note 23 above.

${ }^{36}$ F N L Poynter, 'John Donne and William Harvey', J. Hist. Med. Allied Sci., 1960, 15: 233-46.

${ }^{37}$ William Harvey, Prelectiones anatomiae universalis, (Lumleian Lectures, 1616) facsimile edition, London, J \& A Churchill, 1886; new edition and translation by G Whitteridge, Edinburgh, E \& S Livingstone, 1964. See also William Harvey, Lectures on the whole of anatomy, an annotated translation of Prelectiones anatomiae universalis, by C D O'Malley, F N L Poynter, K F Russell, Berkeley, University of California Press, 1961.
}

\footnotetext{
${ }^{38}$ Wilson presents them as "lecture notes intended not for publication but to be read by their author while he conducted public dissections". See L Wilson,

'William Harvey's Prelectiones: the performance of the body in the Renaissance theater of anatomy', Representations, 1987, 17: 62-95, on p. 62.

${ }^{39}$ See note 19 above.

${ }^{40}$ Bylebyl, op. cit., note 17 above, pp. 368-9.

${ }^{41}$ See note 5 above.
} 


\section{The House Illustration in Ma'aseh Tuviyah (1708)}

new science and the new medicine to students from his own people. One can ask whether Tobias's book could not perhaps directly reflect the lectures he had himself heard at Conegliano's school. Or even, whether he was commanded by his master to write down these lectures in a textbook form. In any case the pedagogical intention seems clear and it is thus not surprising that the author employs mnemonic devices borrowed from the world of architecture and oral culture, while presenting himself as a prophet of learned and literate culture. ${ }^{42}$ Moreover, in Hebrew, we can suppose that Tobias had access to the treatise on rhetoric published by Rabbi Judah alias Messer Leon in Mantua around 1475, one of the first books in Hebrew ever published. ${ }^{43}$ Having compared the manuscripts and the Mantua edition, Rabinowitz even suggests that the book was written first and foremost for medical students as rhetoric was part of their curriculum. ${ }^{44}$ A further study would have to follow a closer comparison between the teaching of memory in Messer Leon's book and the way Tobias has built the body-house mnemonic device presented here. $^{45}$

Similarly, the analogy drawn since antiquity between architecture and its canons and the human body is certainly worthy of further study in this context. ${ }^{46}$ Nevertheless, if one wishes to understand the full sense of the metaphor employed by Tobias, it is important to note both the title of the chapter, 'A New House', and the meaning he ascribes to it in the introduction. In his prefatory remarks, Tobias writes as follows:

$\ldots$ The Sages of old called man a Microcosm. ${ }^{47}$ And that was in the early generations when they were of great stature and their strength was great and their lives ${ }^{48}$ long, and their wisdom vast. And when King Solomon of blessed memory perceived in his wisdom that their strength was expired and their lives shortened and their wisdom lost, he compared man to a city, ${ }^{49}$ saying "there was a

\footnotetext{
${ }^{42}$ See pp. 103-4 below for further discussion of the relationship which existed between Tobias Cohen and Salomon Conegliano.

${ }^{43}$ Judah Messer Leon, The book of the honeycomb's flow: Sepher Nophet Suphim, a critical edition and translation by Isaac Rabinowitz, Ithaca and London, Cornell University Press, 1983 (hereafter Rabinowitz, JML). Two years earlier a facsimile edition of the first edition was published in Jerusalem: Judah Messer Leon, Nofet Zufim on Hebrew Rhetoric, Mantua ca. 1475, with an introduction by Robert Bonfil, Jerusalem, The Jewish National and University Library and the Magness Press (The Hebrew University), 1981. (hereafter Bonfil, JML). The Mantua edition of Messer Leon's book was digitalized and is now online at http://jnul.huji.ac.il/dl/books/html/ bk1929127.htm. On Rabbi Judah Messer Leon, see (in Hebrew) Daniel Carpi, 'Notes on the life of Rabbi Judah Messer Leon', in Carpi, op. cit., note 19 above, pp. 57-84. Note that the Hebrew title of this article is ' $\mathrm{R}$. Judah Messer Leon and his activity as physician'. I would like to thank Reuven (Robert) Bonfil for bringing this work to my attention.

${ }^{44}$ See Rabinowitz, JML, Messer Leon's Preface, p. 11, n. 12 .
}

\footnotetext{
${ }^{45}$ Messer Leon explicitly suggests using "houses and upper stories" as backgrounds for the figures one wants to remember. See Rabinowitz, JML, bk 1, ch. 13.

${ }^{46}$ See, for example, J Rykwert, The dancing column: on order in architecture, Cambridge, MA, MIT Press, 1996, especially pp. 56-90. I would like to thank Andrea Carlino for having drawn my attention to this work. See also Mandressi who has devoted a whole chapter of his book on this issue but without referring to issues of memory. Mandressi, op. cit., note 30 above, pp. 111-32.

${ }^{47}$ Literally "little world". The capital letters, here and elsewhere in the passage, are meant to render typographical accentuations in Tobias's original text.

${ }^{48}$ Literally "their days".

${ }^{49}$ Literally "took man up the hill to the city", perhaps an allusion to the fact that Solomon built the Temple on the heights of Davidic Jerusalem. The Temple is also simply referred to as "The House", and the offerings made there as "risings". The terminology employed is thus rich with traditional connotations.
} 


\section{Etienne Lepicard}

Little City, etc." [Ecclesiastes 9:14]. And I, of little worth, laid to my heart ${ }^{50}$ to enquire what good is it to man that he be compared ${ }^{51}$ to a Microcosm or a City, even a Little City. It is enough that he be as one of the towers or houses among the dwellings of a walled city, ${ }^{52}$ as bars and gates, ${ }^{53}$ as I have shown you the pattern of the house and the pattern of its instruments, as the House of the Soul, ${ }^{54}$ for he has lower, second and a third stories, and an attic and roof above, and walls round about, and corners of the house. And so the wise among the physicians have divided man into three parts and areas, and these are the head, the chest and the abdomen. ${ }^{55}$

This passage cites three stages in the development of the "architectural" metaphor for the human body: first, the human body was compared to a little world, a microcosm, then Solomon compared it to a little city, and finally, Tobias, humblest of all, maintained that it is sufficient to compare the human body to a tower or a house among the dwellings of a walled city. We will come back to this final comparison, but we must first ask ourselves: who are these Sages of old, and who is this king, Solomon? In order to answer these questions let us first examine the Jewish background of Tobias's statement, and then take a closer look at his personal experiences, as he himself describes them, in various parts of the book.

"Great stature" would appear to refer to the giants of chapter 6 in the book of Genesis, who are said to have descended from the heavens and taken unto them the daughters of men. ${ }^{56}$ These giants however, appear in another biblical narrative, more significant for the work of Tobias. Following the exodus from Egypt, Moses sent representatives of each tribe to visit the Promised Land to assess the strength of its inhabitants. Upon their return, the majority of the emissaries spoke of the giants they had encountered there, and the Israelites, terrified by their account, complained to Moses and threatened to return to Egypt. ${ }^{57}$ This allusion to the biblical giants is reinforced by the reference (not translated here) that Tobias himself makes at the beginning of this passage, to his introduction to the fourth chapter of the first part of the book. In this chapter, entitled 'Microcosm', Tobias presents a compendium of knowledge on the subject of man-the ethnographical or anthropological data of the day, so to speak. An entire section is devoted to giants, beginning with the archaeological digs, particularly in Salonika, with which the

\footnotetext{
${ }^{50}$ Tobias uses the exact phrase with which the biblical chapter he has just cited begins: Ecclesiastes 9:1.

${ }^{51}$ Literally "taken up and even raised".

${ }^{52}$ This expression, "dwellings of a walled city" (in Hebrew: "batei "ir homa") is a halakhic category. See below for a discussion of its use in this context. For the sources employed by Tobias, I used the Responsa Project CD-ROM, Version $11+$, Bar Ilan University, 1972-2003, which also includes all the published volumes of Encyclopaedia Talmudica (in Hebrew), vol. 1-25, Jerusalem, Yad Harav Herzog, 1947-2002; see under "Batei 'Ir Homa", vol. 5.

${ }^{53}$ A biblical expression (e.g., Deuteronomy 3, 5; I Samuel 23:7; etc.) that reinforces the idea of a fortress.

${ }^{54}$ In Hebrew, "beit hanefesh". This expression appears only once in the Bible (Isaiah 3:20), in a list of women's adornments. See below for an interpretation of its use in Ma'aseh Tuviyah.
}

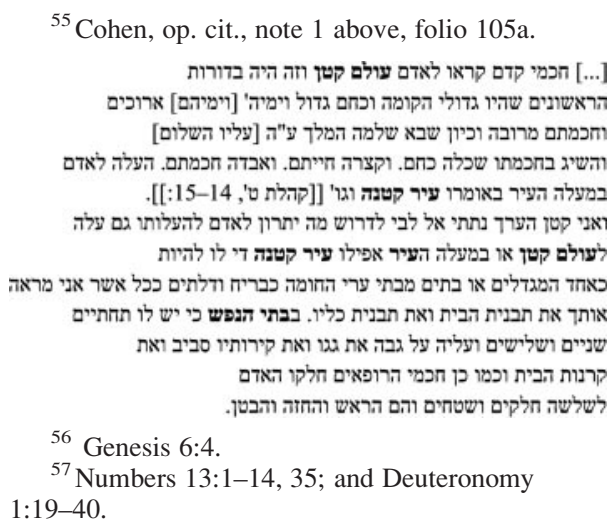

${ }^{57}$ Numbers 13:1-14, 35; and Deuteronomy 1:19-40. 


\section{The House Illustration in Ma'aseh Tuviyah (1708)}

author was familiar. ${ }^{58}$ On the other hand, Tobias's reference to those who compare man to a Microcosm, seems to invoke the origins of scientific knowledge ${ }^{59}$ - which, according to Tobias's adversaries at Frankfurt-on-Oder, could not be found among the Jews. ${ }^{60}$

In Jewish sources, giants are traditionally referred to by seven different names. In part one, chapter four, section three, Tobias cites two of these: "nefilim" and "refaim". The latter word, which also signifies "physicians", albeit with a slightly different inflexion, might provide a further argument in favour of viewing scientific knowledge of the Promised Land as the object of all the author's desires, and the teachers at Frankfurt as embodying the giants barring his way. ${ }^{61}$ The references to King Solomon can also be seen as relating to the origins of scientific knowledge. In fact, they recall a well-known Talmudic legend that Solomon himself wrote a "Book of Remedies", later suppressed by King Hezekiah. ${ }^{62}$ The "little city" mentioned in our text is taken from Ecclesiastes, a book of wisdom attributed to Solomon-further evidence that the Solomon mentioned here is indeed the son of David. ${ }^{63}$ I believe however, that the text can also be read on an entirely different plane. ${ }^{64}$

There was another Solomon, closer to Tobias, who could just as easily have fitted the description here: Solomon Conegliano. At Padua, medical students were organized by "nation", it is not clear, however, whether the Jews constituted one independant group as Dubnov sustained it, but in any case they could have used structures developed by local Jews. ${ }^{65}$ Conegliano was a Jewish physician, who had graduated from Padua and founded a preparatory school for Jewish medical students, attended by Tobias and his friend Gabriel upon their arrival in the city. ${ }^{66}$ In the introduction to his book, immediately following a description of the difficulties he encountered at Frankfurt and the accusations he had faced there, Tobias calls Solomon Conegliano

\footnotetext{
${ }^{58}$ Cohen, op. cit., note 1 above, first part, ch. 4 , 'Microcosm', section 3.

${ }^{59}$ The term microcosm, little world, is neither biblical nor talmudic. It appears, however, in the Midrash and medieval commentaries, e.g. Midrash Tanhuma, Pekudei, 3; or Ibn Ezra (Tudela, 1089$1164)$ in his commentary on Genesis 1:26. For further study, see references note 2 above. On the importance of neologisms in characterizing the debut of scientific literature in Hebrew, see Y T Langernan, 'On the beginnings of Hebrew scientific literature and on studying history through "Maqbilot" (Parallels)', in Aleph: Historical Studies in Science and Judaism, 2002, 2: 169-89.

${ }^{60}$ Cohen, op. cit., note 1 above, folio $6 \mathrm{a}$.

${ }^{61}$ Ibid., and on the names of the giants in Jewish sources, see, for example, Midrash bereshit rabba, critical ed. by J Theodor and C Albeck, Jerusalem, $1965,26,4$.

${ }^{62}$ Mishnah Pesahim 4,9; Talmud Bavli (hereafter TB), Berakhot 10b, TB Pesahim 56a. See Ruderman, op. cit., note 15 above, p. 379.

${ }^{63}$ Ecclesiastes 9:14.
}

\begin{abstract}
${ }^{64}$ Another context worth exploring would be the "Quarrel between the ancients and the moderns", in which the dwarf-giant metaphor was often used. But this is a task beyond the scope of this article. For a thorough introduction to this context within Medieval and Renaissance Jewish thought, however, see Abraham Melamed, On the shoulder of giants: the debate between moderns and ancients in medieval and Renaissance Jewish thought (in Hebrew), RamatGan, Bar-Ilan University Press, 2003. The author dedicates a section of the book to Tobias, which is entitled: 'R. Tobias the Physician, the scientific superiority of the moderns', ibid., pp. 226-32. Quite surprisingly Melamed begins the section saying (in a free translation) "It is not a matter of chance that he [Tobias] has no need of the metaphor of the dwarf and the giant".

${ }^{65}$ See Jacob Shatzky, 'On Jewish medical students of Padua', J. Hist. Med. Allied Sci., 1950, 5: 444-7, on p. 446. This point is also discussed by Ruderman, op. cit., note 15 above, pp. 108-9.

${ }^{66}$ Ruderman, op. cit., note 15 above, pp. 111-12.
\end{abstract}




\section{Etienne Lepicard}

"prince among philosophers and mighty among physicians". ${ }^{67}$ I therefore suggest that the young Jewish student may have seen in Solomon Conegliano the only one to have confronted the force of the giants, and dissolved the magic of their wisdom, restoring his [Tobias's] own dignity and self-confidence. Solomon Conegliano convinced Tobias that scientific knowledge can exist among Jews, and that it can co-exist with the world of the Torah. On a very practical level, the three stages of development of this "architectural/mnemonic" metaphor can be seen as corresponding to three pedagogical devices: the medieval cosmic one, the Coneglian urban one, and the Tobian domestic one. ${ }^{68}$ In the very next sentence, Tobias in fact continues: "And I, of little worth, laid to my heart to enquire what good is it to man that he be compared to a Microcosm or a City, even a Little City. It is enough that he be as one of the towers or houses among the dwellings of a walled city." 69

Returning to the illustration, we observe that the house depicted there corresponds to the metaphor of "one of the towers or houses among the dwellings of a walled city", which in this context can be interpreted as the support of the Jewish community that Tobias found at Padua during his studies. Tobias's use of the halakhic category of "dwellings of a walled city" - houses that could be redeemed within a year of sale if they had been sold out of necessity, but once acquired definitively would never revert to their original ownerscorresponds to the sense of precariousness and then self-confidence he describes in the introduction, following his unhappy experiences in Frankfurt-on-Oder. ${ }^{70}$

In order better to appreciate the metaphor, we will cite the entire verse quoted by Tobias in the traditional Jewish fashion, giving only the first few words:

There was a little city, and few men within it; and there came a great king against it, and besieged it, and built great bulwarks against it; now there was found in it a man poor and wise, and he by his wisdom delivered the city; yet no man remembered that same poor man. ${ }^{71}$

Traditional Jewish sources have subjected the "little city", "few men", "great king" and "poor man" in this story to a wide range of interpretations, presenting them, for example, as the world at the time of the Flood, assailed by the Holy One, blessed be he, with Noah in the role of saviour; Egypt, the Egyptians and Pharaoh, and Joseph as saviour; or Israel at Mount Sinai; or the synagogue. ${ }^{72}$ The interpretation adopted by Tobias, however, is that which sees the human body as the little city, its limbs and organs as the few men, the evil and good inclinations as the great king and the poor man, respectively. The lesson of the entire story, as pointed out by the verses that follow the above citation is: "wisdom is better

${ }^{67}$ Cohen, op. cit., note 1 above, folio 6 a. שר הפילוסופים ואביר הרופאים

${ }^{68}$ There is of course no reason to suppose that Solomon Conegliano and Tobias Cohen were alone in their use of such pedagogical devices. It is far more likely that they were in general use at Padua at that time; a fact that may explain their use by Harvey as well.

${ }^{69}$ Cohen, op. cit., note 1 above, folio 105a.

${ }^{70}$ Ibid., folio $60 \mathrm{a}$.

\footnotetext{
${ }^{71}$ Ecclesiastes 9:14-15: translation from The holy scriptures, Philadelphia, The Jewish Publication Society of America, 1917.

עיר קטנה ואנשים בה מעט ובא אליה מלך וכלך

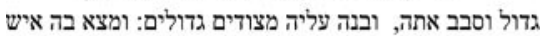

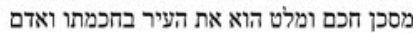

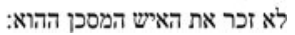

${ }^{72}$ Although far from the most ancient, the most systematic commentary on Ecclesiastes is Midrash
} 


\section{The House Illustration in Ma'aseh Tuviyah (1708)}

than strength", or "wisdom is better than weapons of war". ${ }^{73}$ The metaphor itself is taken up endlessly in Jewish sources-for example, the Talmud, ${ }^{74}$ the Midrash, ${ }^{75}$ and Ibn Ezra. ${ }^{76}$

Finally, let us note the expression "house of the soul", which is a citation from the book of Isaiah (3:20): one of the items on a list of adornments that, according to the prophet, will be taken away from the daughters of Zion as a result of their wicked behaviour. The phrase ${ }^{77}$ has been interpreted in various ways, although traditional biblical commentators have explained it to mean ornaments worn between the breasts, before the heart. ${ }^{78}$ Tobias's use of this expression may denote a desire to render acceptable to religious Jewish students not only the metaphor - in itself quite traditional, as we have seen-but also an illustration that "lays bare" the internal organs, which he suggests be viewed as jewels on the breast of a daughter of Jerusalem.

\section{In Conclusion}

Beyond the fact that it is one of the most beautiful illustrations to be published in a Hebrew medical book of the early modern period, the representation of the human body as a house in Ma'aseh Tuviyah is an expression of the author's perception of man. Like the medieval representation of the Zodiac Man, in which man was often portrayed as a microcosm reflecting a macrocosm, Tobias's "House Man" seems to have fulfilled a same mnemonic function. While an exploration of the arts of memory shows that both metaphors could have lived one with each other during Antiquity and the Middle Ages, the persistence within the early modern period of the house metaphor can also be seen as an alternative to Decartes' metaphor of the functioning of the body as a machine, which relates to the body as detached from the soul. In this sense, the metaphor is indicative of the manner in which iatrochemistry perceived the function of the body as a distillery. In addition, Tobias's accompanying text suggests an original application of traditional Jewish sources, to represent the author's personal experiences: those of a man who needed the support of his community in order to become a physician. Tobias's use of the house metaphor for the body thus demonstrates familiarity with mnemonic pedagogical devices employed at Padua in general, and in Solomon Conegliano's preparatory school in particular; devices Tobias, like Judah Messer Leon in his book on rhetoric before him, took great pains to show-probably for pedagogical reasons-were deeply rooted in Biblical and Talmudic sources.

ecclesiastes rabba (Vilna edition), 9:14 and 15 (the commentary follows the order of the biblical verses). On this Midrash, see H L Strack, and G Stemberger, Introduction au Talmud et au Midrash, Paris, Cerf, 1986, p. 362.

${ }^{73}$ Ecclesiastes 9:16 and 18. טובה חכמה מגבורה טובה חכמה מכלי קרב מכמרה

${ }^{74}$ TB Nedarim 32b. 33,2 .

${ }^{75}$ For example, Bereshit Rabbah (Vilna edition),

${ }^{76}$ Ibn Ezra (Tudela, 1089-1164) on Ecclesiastes 9:14.

\footnotetext{
${ }^{77}$ In the singular in Tobias's text; see note 54 above. In the Pléiade edition of the Bible, for example, Koenig translates "batei hanefesh" as "boîtes à parfum": L'Ancien Testament, ed. E Dhorme, Paris, Gallimard (Bibliothèque de la Pléiade), 1961, vol. 2, p. 14.

${ }^{78}$ Specifically Rashi (Troyes, 1040-1105), Radak (Narbonne, 1160-1235) and Metzudat Tzion (R David Altschuler and his son R Hillel, Prague, seventeenth to eighteenth centuries) on Isaiah 3:20.
} 